\title{
CAIXAS ECONÔMICAS PÚBLICAS E DEPÓSITOS POPULARES NO BRASIL (1861-1940)
}

\author{
PUBLIC SAVINGS BANKS \\ AND POPULAR DEPOSITS IN BRAZIL \\ (1861-1940) \\ Renato Leite Marcondes* \\ Universidade de São Paulo, São Paulo, Brasil, <rlmarcon@usp.br>
}

\begin{abstract}
Resumo. As caixas econômicas públicas foram importantes na captação de depósitos desde a sua criação a partir de 1861 pelo governo imperial e posteriormente pelos estados. Embora a maior parte dos habitantes morasse no campo, as principais capitais provinciais e depois estaduais realizaram elevada proporção de cadernetas de poupança e depósitos em relação à sua população. De forma semelhante, os depósitos das Caixas representaram parcela relevante dos depósitos bancários, comparativamente aos do Banco do Brasil que se expandiram expressivamente nas primeiras décadas do século xx. Após um período de estagnação, a crise dos anos 1930 e a reorganização das Caixas possibilitaram a retomada do crescimento dos seus depósitos.
\end{abstract}

Palavras-chave: caixas econômicas federais; depósitos; poupança; Caixa Econômica Estadual de São Paulo.

\begin{abstract}
The public savings banks were important in attracting deposits since its establishment in 1861 by the imperial government and later by the states. Although most of the inhabitants lived in the countryside, the main provinces and, later, state capitals maintained great proportion of savings account and deposits in relation to its population. Similarly, deposits of public savings banks represented significant portion of bank deposits, compared to the Bank of Brazil that was expanded dramatically in the early decades of the twentieth century. After a period of stagnation, the 1930s crisis and the reorganization of public savings banks allowed the renewed growth in deposits.
\end{abstract}

Key words: federal savings banks; deposits; savings; Savings State of São Paulo.

Artigo recebido: novembro de 2013. Artigo aceito: janeiro de 2014.

* Agradeço a Fundação de Amparo a Pesquisa do estado de São Paulo pelo auxílio regular número 2012/09121-2, que foi fundamental para o desenvolvimento da pesquisa.

Am. Lat. Hist. Econ., año 21, núm. 3, septiembre-diciembre, 2014, pp. 116-143 


\section{INTRODUÇÃO}

$\mathrm{N}$ o último século e meio de história, a economia brasileira transformou-se de modo expressivo. No meado do século XIX, o Brasil era uma economia agrária e empregava ainda largos contingentes de mão-de-obra escrava. Nesse momento, o governo imperial criou uma nova instituição bancária pública de caráter popular no Rio de Janeiro, denominada de Caixa Econômica da Corte em 1861. Apesar das grandes mudanças da economia e as diversas crises brasileiras, esta instituição manteve-se operante de forma contínua e o seu foco no atendimento de um conjunto mais amplo da população.

$\mathrm{Na}$ época da criação da primeira caixa, havia poucos bancos e caixas particulares, que se direcionaram a uma parcela muito reduzida da população, em geral mais rica e próxima aos grandes centros urbanos. Os depósitos bancários difundiram-se principalmente a partir da década de 1830, quando se expandiu a fundação de bancos e caixas econômicas particulares. Todavia, apenas depois de 1850 tais instituições ganharam maior penetração nos grandes centros, mesmo assim o sistema bancário no Império manteve-se bastante limitado. Zélia Cardoso de Mello (1985) verificou na sua amostra de inventários da capital paulista a presença de depósitos e letras bancárias entre os seus inventariados: "Depois de registrado um caso de conta em banco (1855), começam a aparecer casos de dinheiro depositado a juros e letras bancárias, dois em 1863, seis na década de 70, onze nos anos 80 e seis entre 1890-1895" (p. 90). A maior participação desse ativo na riqueza ocorreu no final do período (1888-1895), representando $4.4 \%$ do total dos patrimônios. Nesse último período, os inventariados das faixas de riqueza intermediária e mais rica mantinham participações pouco maiores do que os da faixa dos menos abastados (Cardoso, 1985). Considerando a capital do Império que era mais urbanizada, Zephyr Frank (2004) notou, para uma amostra de inventários, um crescimento significativo dos depósitos bancários na riqueza, chegando a 12.9\% entre 1890 e 1895 comparativamente a $16.1 \%$ em ações e títulos e $6.1 \%$ em dinheiro, bastante acima das informações paulistas. Por fim, Luiz Fernando Saraiva (2002) ao analisar os 28 inventários dos principais cafeicultores de Juiz de Fora (Mina de Gerais) entre 1888 e 1900 verificou que apenas quatro detinham dinheiro em conta de bancos, seis títulos da dívida pública e três dinheiro com comissários. No período anterior (1870-1887), nenhum dos 41 cafeicultores detinha dinheiro em conta de banco nos inventários consultados. Deste modo, evidencia-se a pouca penetração das contas em bancos mesmo entre a população mais abastada até o final do império.

Os poucos bancos em operação na época encontravam-se bastante distantes das camadas mais populares da sociedade, o que mais se aproxi- 
mava eram casas bancárias, porém havia grande instabilidade dessas instituições. Embora fossem companhias, as casas bancárias faziam principalmente de descontos, detendo uma regulamentação mais fácil e menores exigências de capitais para sua constituição do que um banco. Durante a crise financeira de 1864, muitas casas bancárias fecharam as portas deixando correntistas com seus recursos bloqueados, como foi o caso da Souto que era a maior (Müller, s. f.; Sáez, 2010). Tais crises dificultavam o estabelecimento da confiança nessas instituições para recolher depósitos de um amplo conjunto da população. A fundação de um banco de depósitos direcionado para essa finalidade só poderia ser viável naquele momento como instituição pública. Na década de 1870, outras caixas do governo imperial foram criadas nas capitais províncias.

Apesar do foco diferenciado e longevidade dessas instituições financeiras, as caixas foram pouco destacadas pela historiografia econômica e financeira, embora mais recentemente alguns novos estudos discutam a sua história (Adams, 2005; Bueno, 2002; Costa, 2012; Grinberg, 2011). Numa primeira seção, apresentamos a criação da instituição e a difusão dos depósitos populares, salientando também o perfil mais geral dos depositantes. Na segunda seção, destacamos a importância relativa das caixas públicas federais no sistema financeiro nacional, comparando com o Banco do Brasil e movimento bancário mais geral. ${ }^{1}$ Por fim, ressaltamos a instituição de caixas estaduais, principalmente a paulista que foi importante para a difusão da captação de depósitos pelo interior do estado. Assim, nesse artigo tentamos contribuir para entender o alcance dos depósitos das caixas na população e economia brasileira desde a segunda metade do século XIX, tentando avaliar o alargamento das relações bancárias antes da grande expansão após a segunda grande guerra.

\section{DIFUSÃO DOS DEPÓSITOS}

Após um período bastante expansivo do meio circulante e de crises, a lei dos entraves de 1860 procurou restringir as emissões monetárias dos ban$\cos ^{2}$ Apesar de limitar emissões e a formação de bancos, esta lei procurou criar uma alternativa de forma mais confiável de poupança e empréstimo para a população menos abastada. As caixas econômicas deveriam ser ins-

\footnotetext{
${ }^{1}$ A constituição de um sistema financeiro nacional ocorreu ao longo do século XX com o avanço das instituições públicas e privadas após a primeira grande guerra e principalmente depois a segunda grande guerra. Tal processo culminou na reformulação do sistema após 1964, com nova regulamentação e a criação do Banco Central.

${ }^{2}$ Lei 1.083 de 22 de agosto de 1860, recuperado de http://www.planalto.gov.br/ccivil_03/ Leis/LIM/LIM1083.htm.
} 
tituições beneficentes, que receberiam depósitos até certo limite e encaminhariam os saldos à Fazenda nacional. ${ }^{3}$ Por fim, o Monte Socorro proposto conjuntamente realizaria empréstimos por meio do penhor de objetos de valor, como ouro, prata, joias e pedras preciosas.

Logo no início do ano seguinte, uma nova legislação específica autorizou a criação de uma caixa econômica e do Monte Socorro na corte, que começou a funcionar em novembro. $\mathrm{O}$ decreto 2.723 de 12 de janeiro de $1861^{4}$ declara "A Caixa Econômica estabelecida na cidade do Rio de Janeiro tem por fim receber a juro de $6 \%$, as pequenas economias das classes menos abastadas, e de assegurar, sob garantia do Governo Imperial, a fiel restituição do que pertencer a cada contribuinte [...] As quantias depositadas na Caixa Econômica, e remetidas diariamente ao Tesouro são por este garantidas ao depositante."

Como destaca Keila Grinberg (2011), nos seus primeiros anos de atuação a caixa realizou mais penhores do que depósitos, apenas após a crise de 1864 que os segundos superaram os primeiros. A partir dessa época, os penhores representaram cada vez mais uma fração menor dos depósitos, crescendo os saldos remanescentes aplicados em títulos públicos que se tornaram um importante mecanismo de financiamento do Estado no império e início da república (Adams, 2005). ${ }^{5}$ Como as aquisições diretas dos títulos públicos eram muito caras para a maior parte da população, o governo tornou possível, por meio das caixas, ampliar os financiadores do Estado, possibilitando um rendimento próximo ao das apólices públicas à poupança popular. Assim, mesmo que de forma indireta, um conjunto mais amplo da população financiava o Estado brasileiro.

Algumas medidas tomadas pelo governo auxiliaram na expansão da captação dos depósitos. A promulgação da lei do ventre livre em 1871 reconhecendo o direito dos escravos a formar pecúlio também deve ter auxiliado na expansão dos depósitos, que poderiam ser utilizados para alforria. ${ }^{6} \mathrm{O}$ decreto de criação da caixa não admitia como depositantes: menores, escravos e indivíduos que não tiverem a livre administração de sua

${ }^{3}$ A vocação mais popular da caixa foi estabelecida desde o seu início, pois os valores semanais depositados não deveriam superar $50 \$ 000$ reis e se o total depositado ultrapassasse quatro contos deixaria de render juros. O rendimento da aplicação deveria se assemelhar a dos títulos públicos de $6 \%$ ao ano, mas foi posteriormente reduzido em vários períodos. Como as caixas eram tratadas como assistência social, elas não eram computadas no movimento bancário e, talvez por isso, muitos estudiosos dos bancos não as incluíram em suas análises.

${ }^{4}$ Recuperado de http://www2.camara.leg.br/legin/fed/decret/1824-1899/decreto-2723-12-janeiro-1861-556013-publicacaooriginal-75580-pe.html

${ }^{5}$ De acordo com o balanço da Caixa do Rio e de São Paulo em 1924, os valores dos depositantes (passivo) equivaliam-se, grosso modo, ao em conta corrente no Tesouro Nacional ou na Delegacia Fiscal de São Paulo (ativo), respectivamente.

${ }^{6}$ Lei 2.040 de 28 de setembro de 1871, recuperado de http://www.planalto.gov.br/ccivil_03/ Leis/LIM/LIM2040.htm. 
pessoa e bens. Isto não impediu que menores e mulheres estivessem entre os primeiros depositantes das Caixas, como veremos adiante. Ademais, existiam depósitos de escravos antes do ventre livre, mas com o consentimento dos senhores. Além da caixa outras instituições recebiam depósitos de escravos, como uma firma que quebrou na crise de 1864 (Grinberg, 2011). O próprio avanço do trabalho assalariado urbano, e posteriormente no campo favoreceu também a expansão dos depósitos ao longo de todo o período em questão.

Para alargar as operações, o governo autorizou a criação de caixas provinciais em 1874, sediadas nas suas capitais. ${ }^{7}$ Apesar do crescimento das operações provinciais, os recursos depositados nessas caixas mantiveram-se muito inferiores ao da corte até a década de 1880. Dos pouco mais de 15000 contos de réis depositados nas dezessete caixas existentes em 1881, a da corte mantinha dois terços do total $(66.6 \%) .{ }^{8}$ Seis anos mais tarde a participação da corte reduziu-se um pouco, mas ainda detinha mais da metade do total dos depósitos em todas as caixas $(58.5 \%) .{ }^{9}$ Durante o Encilhamento, ocorreu uma transformação expressiva da distribuição regional dos depósitos das caixas, reduzindo a participação dos depósitos da corte a $28.0 \%$ em $1893 .{ }^{10}$ A partir do final do século XIX a participação da Caixa do Distrito Federal no total dos depósitos manteve-se ao redor de três décimos do total. Após a primeira grande guerra a parcela dessa instituição elevou-se a e quatro décimos (40.4\%) em 1925, chegando a 46.4\% em 1930. ${ }^{11}$ Em todo o período considerado essa Caixa do Rio de Janeiro foi a maior de todas.

Uma tentativa de avaliar a difusão dos depósitos das caixas consiste em comparar o crescimento do número de cadernetas em circulação e dos valores reais em relação ao da população das cidades onde atuam. Utiliza-

${ }^{7}$ Decreto 5.594 de 18 de abril de 1874, recuperado de http://www2.camara.leg.br/legin/ fed/decret/1824-1899/decreto-5594-18-abril-1874-550201-publicacaooriginal-65862-pe.html. Em 1878, já existiam doze caixas nas principais províncias.

${ }^{8}$ De acordo com os Relatórios do Ministério da Fazenda (Brasil, 1884, Tabela 24). A segunda caixa em termos de valores depositados foi a do Pará (6.6\%), seguida pela Bahia (4.7\%) e Rio Grande do Sul (4.0\%). Os valores apresentados nos relatórios do Ministério não são iguais aos da série histórica publicada nos relatórios das caixas posteriormente, mas em geral próximos em ordem de grandeza.

${ }^{9}$ Relatórios do Ministério da Fazenda (Brasil, 1890, Tabela 19). A segunda caixa em termos de valores depositados foi a da Bahia (11.2\%), seguida pelo Rio Grande do Sul (5.1\%), Pernambuco (3.7\%) e São Paulo (3.4\%).

${ }^{10}$ Relatórios do Ministério da Fazenda (Brasil, 1895, Tabela 20). As demais caixas em ordem de valores depositados foram as seguintes: São Paulo (15.3\%), Pernambuco (10.2\%), Rio Grande do Sul $(9.4 \%)$ e Bahia e Pará (5.7\%).

${ }^{11}$ Em 1912, São Paulo detinha 19.7\% dos depósitos das caixas, Rio Grande do Sul 10.7\% e Pernambuco 7.3\%. Em 1930, São Paulo perfez 29.4\% dos depósitos das caixas, Pernambuco 5.5\% e o Rio Grande do Sul 4.2\% (ver Instituto Brasileiro de Geografia e Estatística, 1941, pp. 1390-1391). 
mos para o deflacionamento o índice de preços de Goldsmith (1986, pp. 30-31) de 1861-1869, de Catão (1992) de 1870 a 1913 e da cidade do Rio de Janeiro de 1914-1940. Embora existissem agências fora do distrito federal na província do Rio de Janeiro, como Petrópolis e Niterói, verificamos que a maior parte dos depósitos vinculava-se à população do município carioca, assim não incluímos os moradores da província fluminense. Em 1940, todas as dezenove agências de depósitos encontravam-se no Distrito Federal, extinguindo as da província.

Conseguimos levantar dados para as caixas do Rio de Janeiro e de São Paulo desde o seu início de operação, que eram as cidades mais populosas do Brasil. ${ }^{12}$ No gráfico 1, apresentamos o número de cadernetas e os valores reais dos depósitos por 1000 habitantes da Caixa do Rio. Notamos um rápido crescimento na segunda metade da década de 1860 e início da seguinte. Posteriormente, a tendência continuou crescente, mas em ritmo menor e até certa retração ao final do Império. O Encilhamento produziu uma divergência nas duas séries, pois o número de cadernetas continuou a aumentar e, ao contrário, os valores reais estagnaram em face de uma maior elevação dos preços durante o período. $\mathrm{O}$ efeito oposto teve a crise do início do século XIX, quando a deflação aumentou os valores reais depositados, mas acompanhados de até uma redução do número de cadernetas per capita. De modo semelhante, a inflação durante a primeira guerra também produziu uma retração dos montantes depositados em termos reais, todavia as cadernetas se mantiveram. Após a guerra, a recuperação das cadernetas mostrou-se bastante vigorosa nos anos 1920, mas ainda não acompanhadas pelos depósitos que se depreciaram pela inflação significativa na época. A grande depressão levou a uma deflação mais expressiva no início dos anos 1930, o que elevou sobremaneira os valores depositados nas caixas. Os depósitos também cresceram em razão das incertezas do período e a busca por instituições mais confiáveis, como as públicas. Por fim, a reformulação das caixas no início dos anos 1930 permitiu maior facilidade nos empréstimos, atraindo mais depositantes e depósitos.

As caixas já realizavam empréstimos por meio de caução de títulos desde Decreto 11.820 de 15 de dezembro de $1915,{ }^{13}$ mas passaram a fazer consignados a funcionários públicos após o decreto 20.225 de 18 de julho

${ }^{12}$ As cidades do Rio de Janeiro e São Paulo detinham, em 1940, 1750000 e 1320000 habitantes, respectivamente. O crescimento demográfico paulista foi superior a carioca no período considerado. Salvador e Recife apresentam 289000 e 343000 moradores em 1940, sendo muito menores do que as duas principais cidades do país. A população rural carioca e paulistana representavam apenas $13.9 \%$ e $5.1 \%$ do total nesse ano. Tais dados demonstram a importância do Rio de Janeiro e São Paulo e de sua urbanização.

${ }^{13}$ Recuperado de http://www2.camara.leg.br/legin/fed/decret/1910-1919/decreto-11820-15-dezembro-1915-511987-publicacaooriginal-1-pe.html. 
de $1931^{14}$ e hipotecas a partir do Decreto 24.427 de 19 de junho de $1934 .^{15}$ Embora a lei sobre empréstimos hipotecários ocorresse apenas em 1934, já havia uma autorização anterior de 1931 que permitia tais operações. A ampliação das operações de empréstimos em termos de valores e tipos diferentes deve ter facilitado a captação de depósitos. Este último decreto criou o Conselho Superior das Caixas, permitindo maior autonomia às caixas e facilitou a sua expansão.

Nessa década, a tendência das duas variáveis mostrou-se crescentes, bem como na maior parte do período em questão. Assim, a correlação entre o número de cadernetas e os totais depositados em termos reais na Caixa do Rio revelou-se muito elevada (0.917), descrevendo movimentos conjuntos das séries.

Já no final da década de 1870, existia cerca de uma caderneta para dez habitantes na capital federal. Devemos lembrar que algumas pessoas poderiam ter mais de uma caderneta em função dos limites de depósitos, porém nesse caso o recebimento de juros seria limitado. Segundo o Almanaque de São Paulo de 1888, só havia o recebimento dos juros para a primeira caderneta de cada um, não recebendo as demais (Seckler, 1888, p. 136). Não temos uma clara referência à quantidade de pessoas nessa situação, pois alguns faziam depósitos para filhos, netos etc. O limite para pagamento de juros foi ampliado posteriormente. Infelizmente, não dispomos de microdados dos depósitos e seus depositantes, nem mesmo sabemos se existem. Antes da primeira grande guerra, a proporção aumentou para uma para cada cinco moradores. Por fim, na década de 1930 chegou ao redor de um a cada três detinha uma caderneta da caixa. Em São Paulo, as proporções mantiveram-se sempre mais reduzidas do que as cariocas, atingindo apenas ao final da década de 1930 a proporção de uma caderneta para quatro habitantes, como visto no gráfico 2 abaixo. ${ }^{16}$ De toda sorte, a difusão de cadernetas entre a população mostrou-se bastante expressiva e crescente na população urbana dos grandes centros.

O perfil dos novos depositantes da Caixa do Rio de Janeiro salienta a difusão pela sua população. A presença de menores foi bastante regular, já entre os primeiros 49 depositantes na Caixa da Corte em novembro de 1861 havia doze menores e treze mulheres, das quais quatro os depósitos

\footnotetext{
${ }^{14}$ Recuperado de http://www2.camara.leg.br/legin/fed/decret/1930-1939/decreto-20225-18-julho-1931-503695-publicacaooriginal-1-pe.html.

${ }_{15}$ Recuperado de http://www2.camara.leg.br/legin/fed/decret/1930-1939/decreto-24427-19-junho-1934-498355-norma-pe.html.

${ }^{16}$ Dispomos de uma série para a Bahia (1878-1933), que revela uma difusão de cadernetas e de depósitos reais ainda menores do que em São Paulo e principalmente a do Distrito Federal. A proporção soteropolitana atingiu uma caderneta para cinco habitantes ao final da década de 1920 . Assim, como esperado, os grandes centros concentram o movimento financeiro.
} 


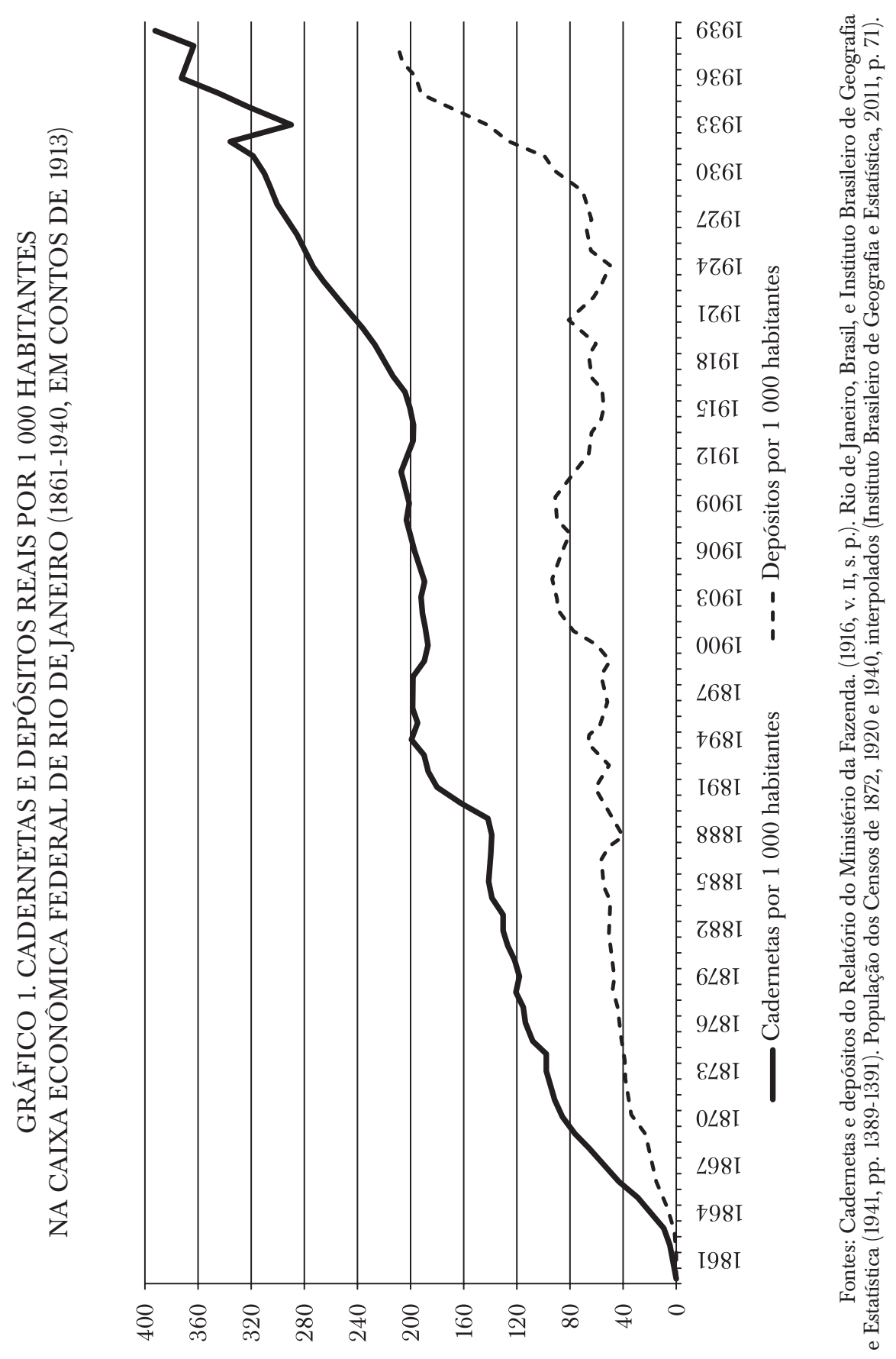


foram efetuados pelos seus pais (Bueno, 2002, p. 31). Keila Grinberg (2011, p. 154) salienta a transformação do perfil dos depositantes, tornando-se mais populares na década de 1880. A partir de 1882 as informações dos novos depositantes tornaram-se mais regulares nos relatórios do Ministério da Fazenda, apresentando os estrangeiros um número maior aplicadores do que os nacionais nesse ano e no seguinte, ressaltando a presença na cidade de imigrantes enriquecidos, como portugueses. Posteriormente, os nacionais aumentaram continuamente sua participação, chegando a pouco mais de um terço no início do século XX e já superaram os estrangeiros em 1924 (72.9\%). Em termos de profissões declaradas, mais de três quartos eram trabalhadores urbanos entre 1882 e 1892 (79.4\%), pois a população rural da cidade mostrava-se reduzida. ${ }^{17}$ Esta proporção de trabalhadores não agrícolas reduziu-se para cerca de dois terços de 1895 a 1908 (66.8\%), mas ainda muito elevada sua representatividade. Já em 1924, a classificação das profissões alterou-se em relação à nomenclatura anterior, porém a maior parte continuava a atuar como operários (24\%), domésticos e trabalhadores $(29.0 \%)$ e na indústria, comércio e transporte (27\%). Por fim, os liberais e os da lavoura detinham pequena participação em 1924 (9\% e $3.1 \%$, respectivamente).

A participação dos menores na Caixa do Rio manteve-se ao redor de um sexto do total entre 1882 e 1892 (15.9\%). De outro lado, as mulheres realizaram grande parcela dos depósitos, atingindo pouco mais de um terço entre 1891 e $1908(35.1 \%)$ e aumentaram a sua parcela para $40.5 \%$ em 1924.

Na caixa baiana, a proporção de mulheres no total chegou a $45.4 \%$ entre 1906 e 1914 (ver Brasil, 1906, 1909 e 1914). Também na Bahia, os trabalhadores urbanos destacavam-se no total de depositantes nesses anos, respondendo por mais de dois terços dos com profissão declarada (70.4\%). A participação feminina na população economicamente ativa brasileira foi de $15.7 \%$ em 1920 e de 19.0\% em 1940 (ver Marques e Melo, 2008, p. 488). Apesar da diferença do espaço considerado que favorece a maior presença feminina nas capitais, a proporção de depósitos muito mais elevada do que na renda decorre também de uma estratégia de proteção delas, muitas vezes com o amparo de maridos e pais. O Almanaque de São Paulo de 1888 informa as condições dos depósitos sob alguma tutela:

mulheres casadas, sob qualquer regime, podem livremente instituir e retirar depósitos em seus nomes, salvo intervindo oposição por parte dos maridos. É igualmente permitido aos menores fazer depósitos, sem intervenção dos seus representantes

${ }^{17}$ Consideramos como trabalhadores urbanos: operários e artistas, trabalhadores, criados e empregados do comércio e indústria, excluindo os casos sem profissões. 
legais, bem como retirá-los, se tiverem mais de 16 anos de idade, salvo aparição dos ditos representantes, cujo concurso se deverá exigir no ato do pagamento. $\mathrm{O}$ depósito em favor de escravo deverá indicar o nome do senhor, e só poderá ser retirado com autorização do Juiz de Órfãos (Seckler, 1888, pp. 136-137).

Nesse último ano, houve a informação dos valores por sexo, nacionalidade e analfabetismo dos novos depositantes. Embora os que não sabiam escrever fossem quatro décimos do total de depositantes em 1924 (40.1\%), a parcela dos valores detida pelos analfabetos foi apenas um pouco menor $(38.5 \%)$, não havendo grande discrepância na proporção entre dois grupos. ${ }^{18}$ Ainda em termos de valores, os estrangeiros detinham uma participação muito maior do que em número nesse ano (37.4\%), salientando maiores valores depositados por eles. De forma semelhante, as mulheres também apresentavam uma proporção um pouco maior dos valores do que do número de cadernetas em 1924 (43.9\%). ${ }^{19}$ Desta forma, os estrangeiros e as mulheres revelaram um perfil de maiores valores do que os demais. Devemos lembrar que mesmo voltada à população menos abastada, as caixas ainda exigiam a existência de poupança monetária, excluindo os mais pobres do acesso à instituição.

A Caixa Econômica de São Paulo foi criada em 1875. A tendência inicial de crescimento das cadernetas e depósitos mostrou-se expressiva. A crise no final do Império foi mais notória no caso paulistano, bem como a crise do final do século XIX em face a preços menores do café naquele momento. Posteriormente, a recuperação da tendência de crescimento foi bastante expressiva no início do século XX até a primeira grande guerra, reproduzindo o vigor da economia paulistana nessa época. A guerra reduziu fortemente os valores reais dos depósitos e se manteve em patamares reduzidos durante a década de 1920, recuperando somente durante a grande depressão, como ocorreu na Caixa do Rio. ${ }^{20}$ As cadernetas não apresentaram tal retração e continuaram a aumentar em termos da população até o final do período, havendo apenas uma pequena diminuição du-

${ }^{18}$ Os valores médios dos depósitos novos dos alfabetizados e não foram os seguintes em 1924: 780000 e 729000 réis, respectivamente. A proporção de pessoas que não sabiam ler e escrever entre os depositantes mostrou-se semelhante à entre os habitantes do Distrito Federal no censo de 1920 (38.7 per cento).

19 Tal resultado decorreu, em grande parte, dos valores depositados para os menores do sexo feminino serem muito superiores aos do masculino, que foram os seguintes em média: 588 e 399 mil réis. Talvez reflitam uma estratégia diferente dos pais com relação às filhas em relação aos filhos. Por outro lado, nos valores médios depositados pelos maiores a diferença entre os sexos também foi favorável às mulheres: 1000 e 913000 réis. Por fim, os valores depositados pelos menores eram em média bem inferiores aos dos maiores, em cerca da metade.

${ }^{20}$ A correlação entre os depósitos reais das caixas do Rio e de São Paulo mostrou-se elevadíssima (0.989). 
rante a crise do início dos anos 1930. Apesar das diferenças entre a série de número de cadernetas e valores reais depositados, elas correlacionaram-se fortemente em todo o período em consideração (0.948).

O perfil dos novos depositantes da Caixa de São Paulo não se mostrou muito diferente da do Rio, embora algumas características distintivas devam ser destacadas pela própria demografia paulistana diferir da carioca. Infelizmente não dispomos de relatórios do século XIX, utilizamos dois relatórios de 1909 e 1914 da caixa como referência do perfil antes da primeira grande guerra e dois outros de 1925 e 1930 do entre guerras. Como o movimento imigratório estrangeiro foi maior para São Paulo, a presença dos estrangeiros revelou-se um pouco maior na caixa paulistana, perfazendo quase a metade do total antes da guerra (47.3\%), mas reduzindo posteriormente a $36.0 \%$. Tal retração refletiu o menor movimento migratório posteriormente a primeira grande guerra. Em termos etários, os menores mantiveram a sua participação entre os novos depositantes da caixa paulista, se compararmos antes e depois da guerra $-15.8 \%$ em 1909 e 1914 para 16.3\% em 1925. Entretanto, as mulheres elevaram a sua parcela nesses anos de $39.4 \%$ para $42.4 \%$. Estas pequenas indicações das duas caixas salientam o crescente envolvimento delas na esfera financeira.

Os depositantes declaravam profissões ligadas ao trabalho urbano em menor proporção do que a Caixa do Rio, perfazendo pouco mais da metade do total de aplicadores antes da guerra $(60.1 \%)$ e quase três quartos posteriormente a guerra (72.6\%). A parcela de depositantes que sabiam ler e escrever mostrou tendência crescente, passando de $68.1 \%$ em 1914 para 70\% em 1925 e 75\% em 1930, muito superior à da Caixa do Rio e mesmo à da totalidade população paulistana. ${ }^{21}$ Assim, os depositantes paulistanos compreendiam um conjunto expressivo da população, porém menor do que os cariocas, bem como eram mais instruídos e detinham depósitos maiores em média. ${ }^{22}$ De outro lado, a Caixa do Rio conseguiu compreender depositantes mais populares, talvez em razão de uma estrutura de agências mais ampla do que a paulistana.

Dispomos das informações para a totalidade dos depósitos das caixas apenas a partir de 1912. Se compararmos essa série com o conjunto da população das capitais brasileiras, verificamos proporções de depósitos reais per capita semelhantes às da Caixa do Rio até a primeira grande guerra, conforme o gráfico 3. Posteriormente, os depósitos reais per capita

${ }^{21}$ Em 1920, a parcela de pessoas que sabiam ler e escrever na capital do estado foi de 58.3 per cento.

${ }^{22}$ No início das caixas, os depósitos na Caixa do Rio eram maiores do que a paulistana. Entretanto, a partir de 1885 a relação inverteu-se até o fim do período em estudo. Uma ilustração do tamanho da diferença pode ser observada para 1920, quando o depósito médio da Caixa do Rio foi de 472000 réis enquanto na paulistana era de $743 \mathrm{em} 1920$. 


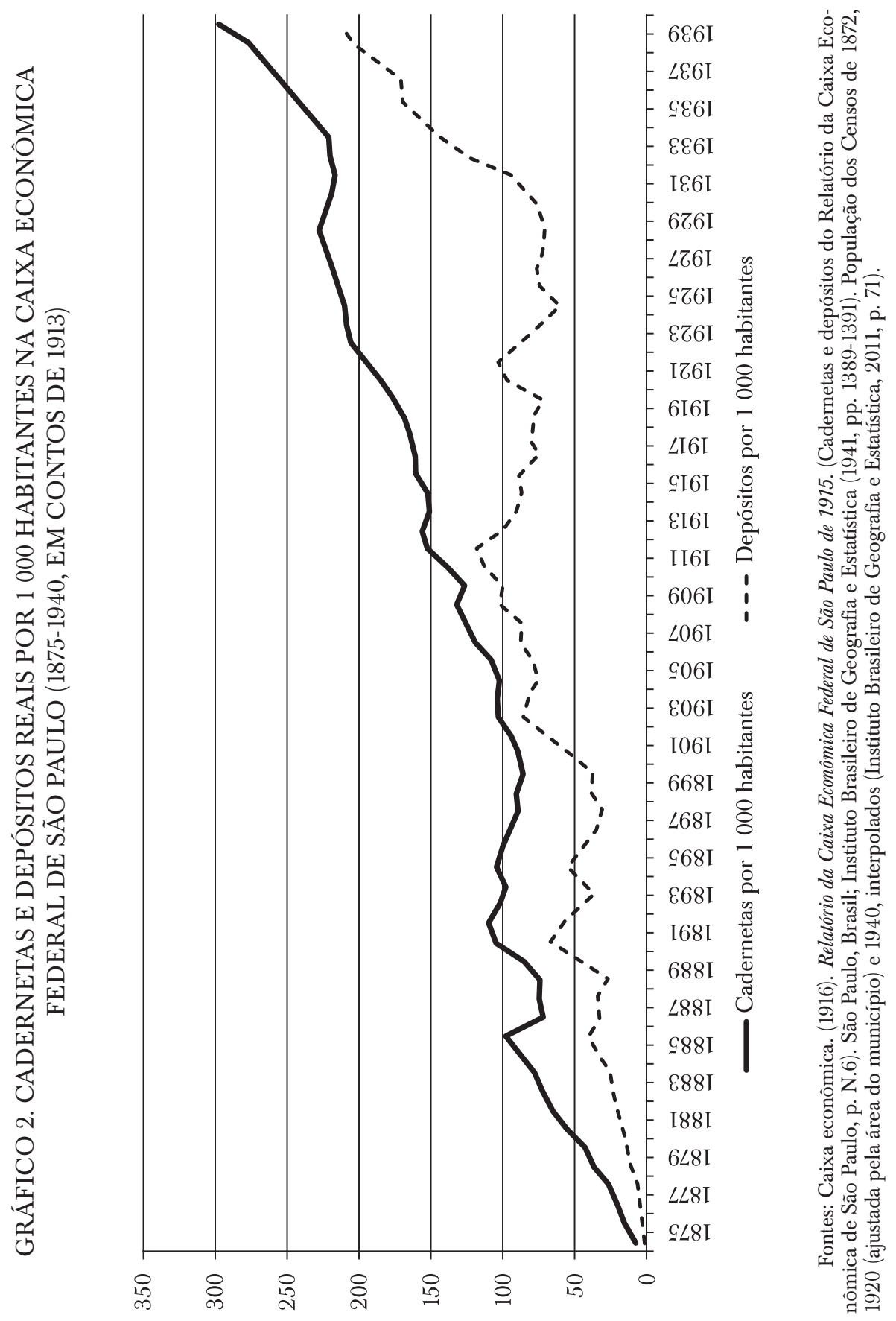


das caixas das capitais representaram proporções cada vez menores com relação aos da Caixa do Rio de Janeiro a partir do final da grande guerra, de $97.2 \%$ em 1917 a $66.4 \%$ em 1935. Por fim, a difusão das cadernetas per capita das caixas econômicas mostrava-se próxima da do Rio, pois alcançou um quinto da população das capitais ao final dos anos $1920(21.1 \% \mathrm{em}$ 1930) e pouco mais de quatro décimos em 1940 (41.9\%). ${ }^{23}$ Assim, como a maior parte da população brasileira não residia nas capitais dos estados, mas principalmente no ambiente rural, essa massa continuava a margem dos depósitos das caixas nos anos 1920 e mesmo durante a expansão dos anos $1930 .^{24}$

O comportamento dos depósitos reais de todas as caixas também demonstra a dificuldade de expansão delas nos anos 1920, ainda mais se compararmos com as demais instituições financeiras, como o Banco do Brasil e mesmo a Caixa Estadual Paulista, que será analisada a seguir. Novamente a reestruturação das caixas nos anos 1930 produziu um aumento extraordinário do número de cadernetas e principalmente dos depósitos reais, não apenas nos anos de deflação, mesmo quando comparamos com outras instituições financeiras.

\section{CAIXAS E O SISTEMA FINANCEIRO}

A expansão do sistema bancário na segunda metade do século XIX facilitou a poupança na economia brasileira, apesar das várias crises chamarem a atenção para os riscos dessas instituições. As caixas econômicas assumiram papel destacado nessa captação dos depósitos, pois eram instituições públicas direcionadas para população menos abastada. Como vimos na seção anterior, o crescimento do número de cadernetas e dos valores reais depositados foi maior que o demográfico nas duas principais cidades do país. Outro modo de avaliarmos a importância das caixas consiste em compará-las com outros bancos.

Um primeiro cotejo pode ser realizado com relação a principal instituição bancária brasileira daquela época: o Banco do Brasil. ${ }^{25}$ Para os primeiros anos de funcionamento da Caixa do Rio realizamos uma com-

\footnotetext{
${ }^{23}$ Devemos lembrar que algumas pessoas mantinham mais de uma caderneta, assim superestimamos a difusão.

${ }^{24}$ Se supuser que cada depositante detêm apenas uma caderneta, apenas $4.1 \%$ da população possuía caderneta da caixa em 1940.

${ }^{25} \mathrm{O}$ Banco do Brasil dessa época foi fruto da fusão do banco do Mauá com o Banco Comercial do Rio de Janeiro em 1853. Houve fusões com o Banco Comercial e Agrícola e o Banco Rural e Hipotecário no início da década de 1860. Por fim, ele fundiu-se com o Banco da República dos Estados Unidos do Brasil, formando o Banco da República do Brasil em 1892.
} 


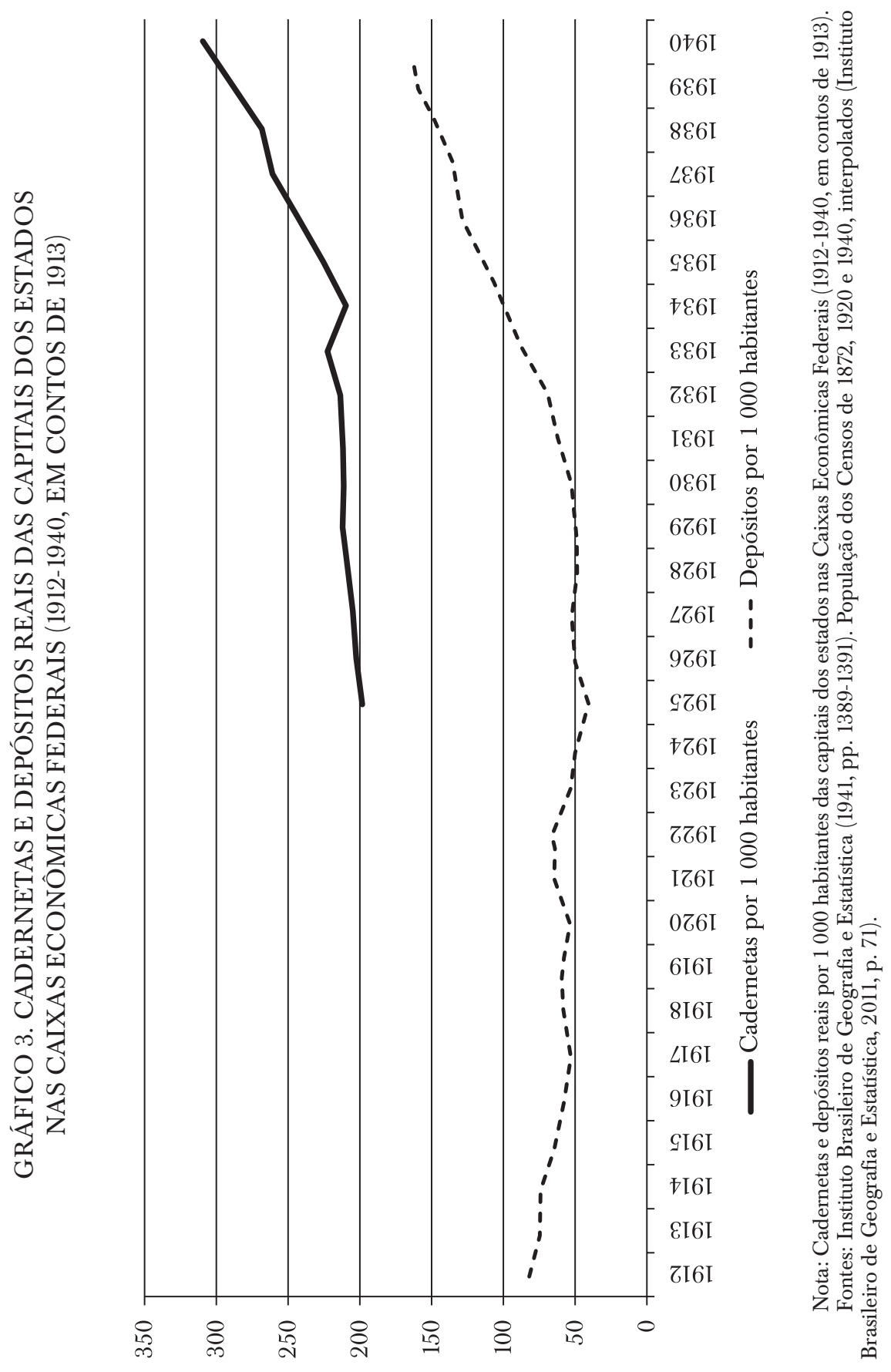


paração dos seus depósitos com os do Banco do Brasil, tanto a vista quanto a prazo (Pelaéz e Suzigan, 1981, pp. 397-408). A proporção dos depósitos da primeira em relação aos do segundo apresentamos no gráfico 4 . Este cotejo salientou o desempenho relativo das instituições em diferentes conjunturas. No início, a participação dos depósitos da caixa proporcionalmente aos do Banco do Brasil mostrou-se bastante reduzida, porém rapidamente cresceu, superando os da instituição mais tradicional já em 1869. Enquanto os depósitos na caixa sempre superaram as retiradas até 1874, a crise do Souto de 1864 e a guerra do Paraguai (1864-1870) afetaram muito mais os depósitos do Banco do Brasil, que se reduziram fortemente em 1863 e 1866-1867. Na década de 1870, a relação retornou ao patamar de um quinto dos depósitos do Banco do Brasil, elevando-a em pequena monta ao final do Império. Nessa década começaram a funcionar novas caixas nas províncias, o que elevou gradualmente os depósitos, como aponta a linha vermelha do gráfico incorporando as Caixas de São Paulo e Bahia à do Rio. O início da República conduz a uma expansão monetária considerável que nos primeiros anos beneficia os depósitos do Banco do Brasil, porém nos anos seguintes há uma estagnação deles aumentando a importância relativa dos das caixas. ${ }^{26}$

A política monetária contracionista do final do século e a crise do Banco da República do Brasil produziram retração nos seus depósitos. Nos anos mais agudos da crise bancária de 1900 a 1906, os depósitos da Caixa do Rio superaram os do banco. A Caixa também sofreu com retiradas maiores do que os depósitos, porém apenas em 1900 e 1905, mantendo suas atividades sem interrupção. ${ }^{27}$ Dessa forma, não realizamos uma comparação nesses anos de crise e nos primeiros do novo Banco do Brasil formado a partir de 1905, como sociedade anônima aberta de economia mista sobcontrole público ao contrário do anterior. De outro lado, como há dados consolidados das caixas federais autônomas e anexas de 1912 a 1940, passamos a realizar as comparações a partir de 1912 não mais com apenas a do Rio, mas todas caixas, pois o novo Banco do Brasil expandirá

\footnotetext{
${ }^{26}$ Se utilizarmos as informações dos Relatórios do Ministério da Fazenda para estimarmos os saldos depositados em todas as caixas provinciais, verificaremos que o valor depositado nas caixas era equivalente ao do Banco do Brasil em 1899.

${ }^{27}$ Franklin de Alencar Lima apresentou, como vice-presidente, o relatório da caixa de 1901, que já demonstrava um quadro de melhora da conjuntura: "Sucedeu ao período crítico do último ano, criado pela situação econômica da praça desta capital, uma fase de operações normais nesta caixa econômica, dando lugar a movimento regular de depósitos [...] Era de prever essa manifestação calma de negócios, resultado do estado do crédito público e da confiança dos depositantes; e por isso, só se verificaram no ano findo [1901] depressões pouco sensíveis nas entradas realizadas no $1^{\circ}$ semestre, mas que foram compensadas pelo excesso havido no $2^{\circ}$ semestre (...)" (Caixa econômica, 1902, p. 8). Além da crise econômica e bancária, ele relatou alguns desfalques de funcionários que também pode ter abalado a confiança dos depositantes, reclamando da impunidade e morosidade da justiça na punição dos três culpados (Caixa Econômica, 1902, pp. 12-13).
} 


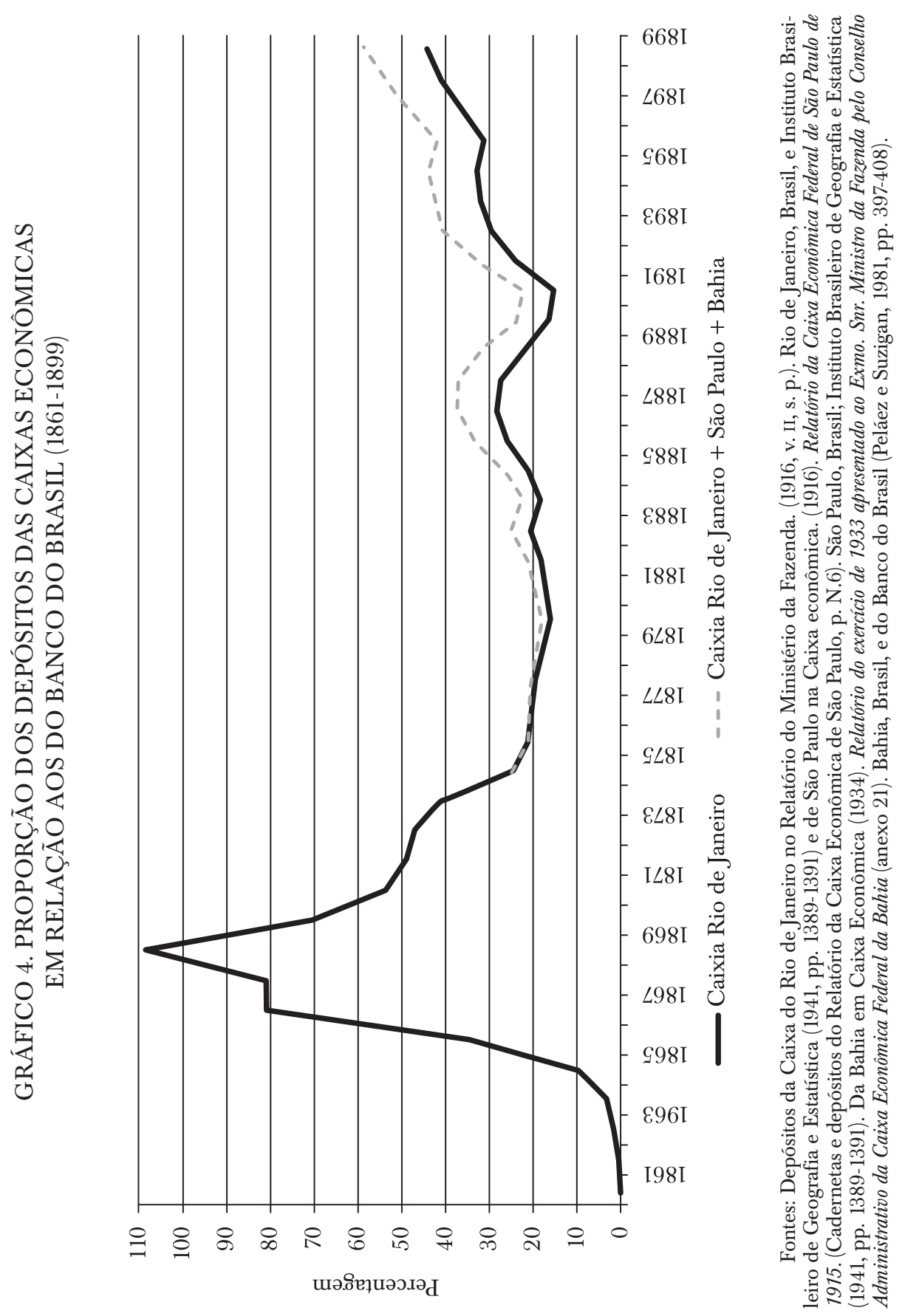


de forma expressiva suas agências inclusive pelo interior. Os resultados podem ser observados no gráfico 5 abaixo, utilizando novamente tanto depósitos a vista como a prazo dessa nova instituição. No início da década de 1910, o Banco do Brasil ainda não conseguiu captar volumes muito expressivos de depósitos e as caixas mantinham tradição nessa função. A partir de 1915, o Banco do Brasil iniciou uma expansão vigorosa de agências em todo território nacional, levando a um aumento da captação de depósitos e a um declínio rápido da proporção do gráfico 5 . Em face da crise da guerra, a lei 2.986 de 28 de agosto de $1915^{28}$ transferiu recursos da União ao Banco do Brasil por meio de emissão de moeda ou de títulos para emprestar a lavoura, indústria e comércio, obrigando-o a abrir agências em todos os estados e o território do Acre. Além de elevar os depósitos máximos das caixas econômicas (sobre a expansão das agências do banco, ver Banco do Brasil, História, 2010, p. 120).

Apesar da grande expansão do Banco do Brasil, as caixas mantiveram depósitos na proporção de cerca da metade do novo banco durante a década de 1920. Por fim, a reorganização das caixas nos anos 1930 permitirá um crescimento expressivo dos seus depósitos, mesmo em relação ao Banco do Brasil que também foi muito atuante nessa época. Assim, verificamos a grande relevância das caixas desde o século XIX em termos dos depósitos relativamente a outra instituição de porte da época.

Ainda podemos compará-las com os dados do sistema bancário e mais gerais da economia para esse período. No gráfico 6 , fornecemos dois outros indicadores dos depósitos das caixas em relação aos depósitos dos bancos consolidados e mesmo ao PIB, de acordo com o Anuário Estatístico do Instituto Brasileiro de Geografia e Estatística (1941) e a estimativa de Haddad (1978), respectivamente. Verificamos que a participação das caixas continua muito relevante em comparação a um conjunto maior de bancos. Nos anos próximos do início da guerra, a participação manteve-se acima de um quinto. Posteriormente, reduziu-se até o final da década de 1920, atingindo cerca de oito pontos porcentuais. Na década seguinte, houve uma recuperação dos depósitos das caixas relativamente aos nos bancos, terminando em quinze pontos. De outro lado, a participação em relação ao PIB, mostrou movimento semelhante, de 3.7\% do PIB em 1912 para menos de dois pontos porcentuais no final dos anos 1920, crescendo na década de 1930 até $4.9 \%$ em 1940. Estes resultados corroboram a grande importância das caixas até a primeira grande guerra, que se retraiu nos anos 1920, mas uma forte recuperação na década seguinte. Assim, verificamos um crescimento relativo das caixas após anos de crise, como

\footnotetext{
${ }^{28}$ Recuperado de http://www2.camara.leg.br/legin/fed/decret/1910-1919/decreto-2986-28-agosto-1915-574919-publicacaooriginal-97996-pl.html
} 


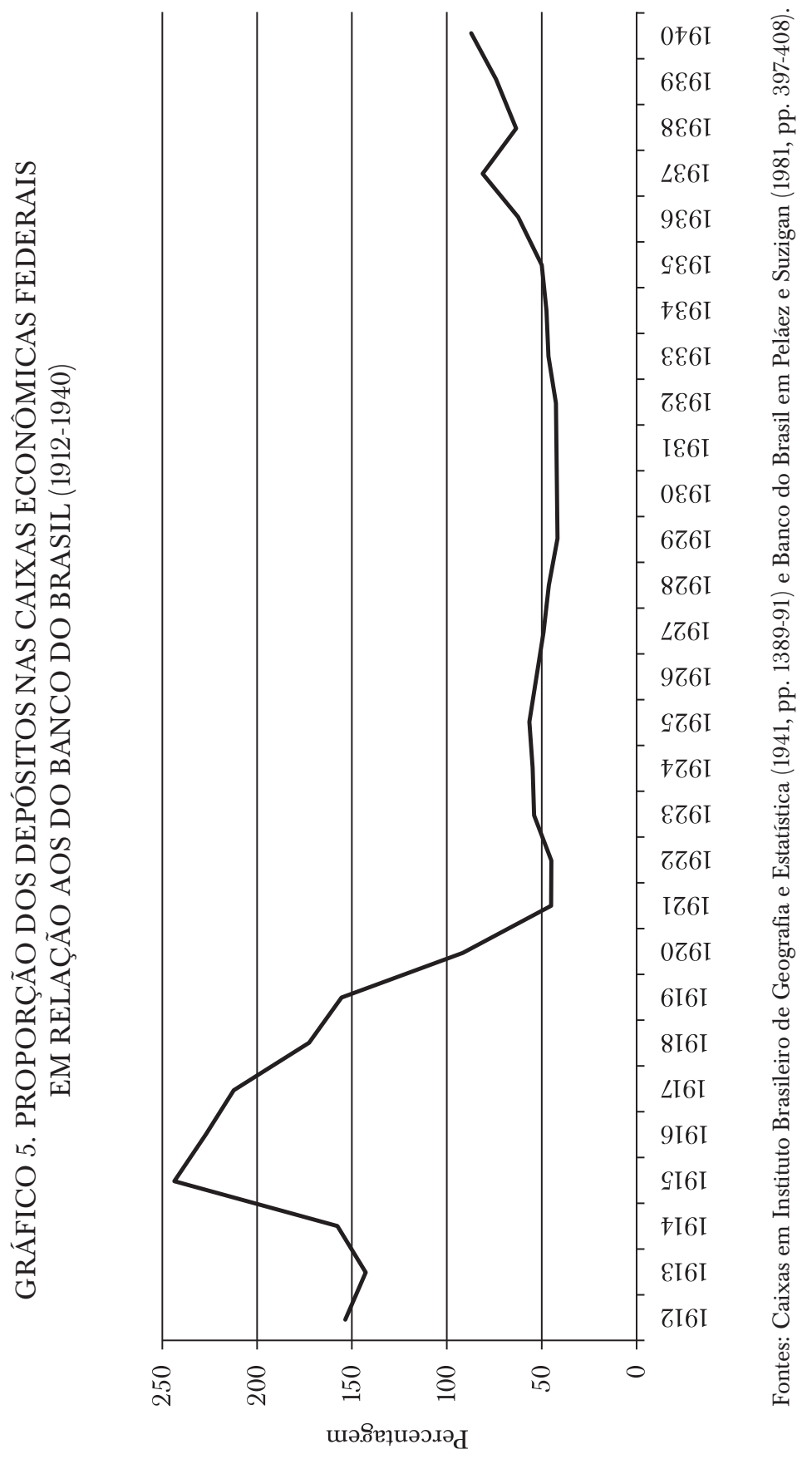


alternativa mais segura para os depósitos e poupadores atraídos também pelas novas operações.

A conjuntura econômica e financeira marcou os novos depósitos e as retiradas das caixas, como o encilhamento e a crise bancária na passagem para o século XX. No período de 1912 a 1940, os movimentos líquidos de saques ocorreram antes e início da primeira grande guerra (1913 e 1914), meado da década de 1920 e no início da crise de 1929, como pode ser observado no gráfico 7 abaixo. No primeiro subperíodo, a perspectiva e depois a eclosão da primeira grande guerra produziu retiradas em grande proporção. No outro momento, os saques não se mostraram tão expressivos em relação aos depósitos totais, mas ocorreram em vários anos seguidos. O fortalecimento da concorrência bancária e as dificuldades das caixas expandirem-se nessa época ajudam a explicar a retração. Por fim, a grande crise de 1929 deve explicar um movimento de saques maiores do que depósitos, mas não tão graves quanto ao do início da primeira grande guerra.

Os movimentos mais intensos de depósitos líquidos ocorreram ao final da primeira grande guerra e a partir de 1931. O encerramento da guerra gerou efeitos positivos para economia brasileira por meio da retomada do comércio exterior, mas não foram sustentados nos anos seguintes em termos de depósitos das caixas. De outro lado, após os primeiros anos mais difíceis da grande depressão e combinado a uma reformulação das caixas houve um grande afluxo continuado de depósitos. ${ }^{29}$

Outra característica dos depósitos ao longo do período de 1912 a 1940 foi a elevação da sua rotatividade. Se até a primeira grande guerra, a razão novos depósitos em relação ao saldo do final de ano deles foi inferior a metade, esta proporção atingiu cerca de 0.6 no meado da década de 1920. A grande crise reduziu os novos depósitos em relação aos totais acumulados, chegando a 0.45 em 1930. Entretanto, passada a crise inicial, as entradas de novos recursos nas caixas cresceram rapidamente, alcançando valores superiores aos totais depositados a partir de 1936. Destarte, a rotatividade dos depósitos acelerou no final dos anos trinta, diminuindo o tempo médio de permanência dos recursos nas caixas. ${ }^{30}$

${ }^{29}$ O diretor da Caixa Baiana Manoel Pinto de Aguiar expressou-se da seguinte forma no relatório de 1933: "Aumentava assim em plena crise econômica e financeira o volume dos depósitos, realizando o espetáculo inédito de poupança em período de crise" (Caixa econômica, 1934, p. 15).

${ }^{30} \mathrm{O}$ movimento das retiradas mostrou-se bastante próximo das entradas de novos depósitos, apresentando uma correlação muito próxima de um (0.998). 


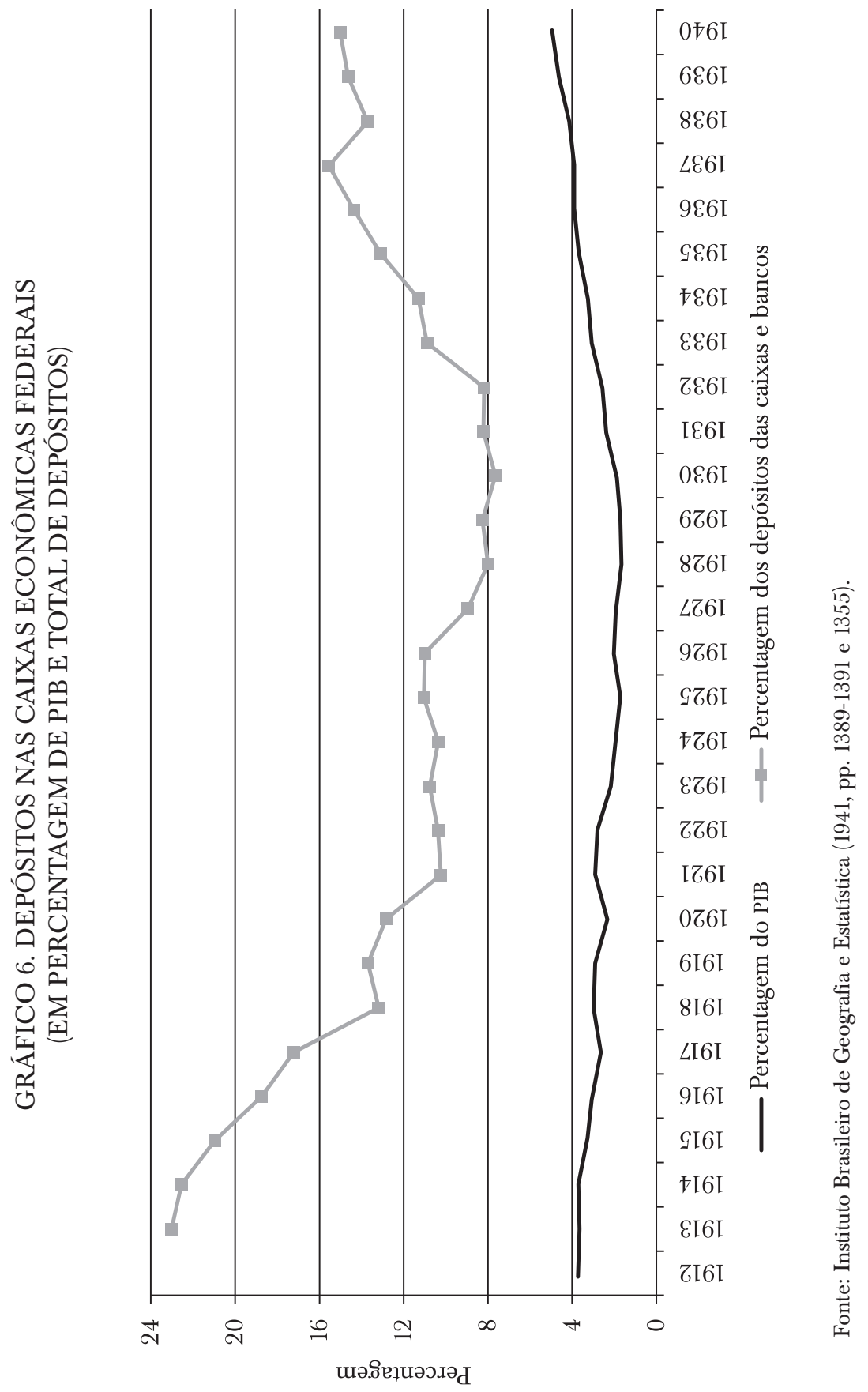



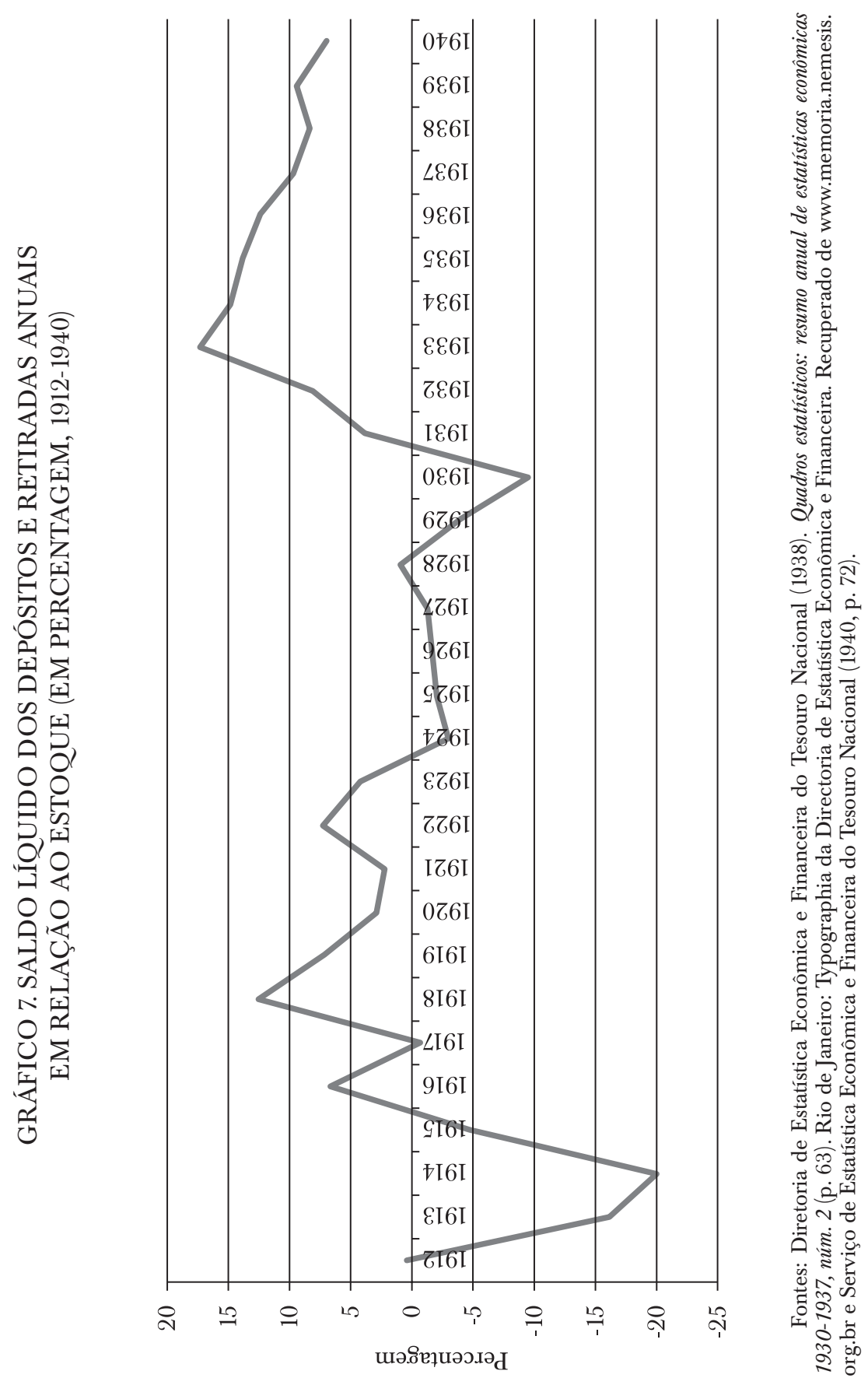


\section{Caixas Estaduais}

Como notamos anteriormente, havia uma grande concentração dos depósitos em termos regionais no Distrito Federal e em segunda monta no estado de São Paulo no início do século Xx. Estas duas áreas representavam pouco menos de três quartos dos depósitos das caixas em todo o período, perfazendo 73.4\% em 1928 e $72.3 \%$ em $1940 .{ }^{31}$ Além das caixas federais, existiam nessa época as caixas estaduais em Minas Gerais (desde 1896) e São Paulo (desde 1916), que também recolhiam depósitos populares. ${ }^{32}$

A caixa mineira foi instituída pela Lei estadual 210 de 19 de setembro de 1896, regulamentada pelo decreto 1.030 de 28 de abril de 1897 . O governo do estado garantia os depósitos e recebia dinheiro a prêmio. Posteriormente, em face às dificuldades de manter a instituição, o governo estadual suspendeu os novos depósitos, encaminhando para a caixa federal, como relata o presidente da província em 1924: "Sustou em todas as agências a emissão de novas cadernetas [...] Suspendeu os depósitos subsequentes em todos os lugares onde existem bancos ou agências bancárias e pretende liquidar gradualmente as agências destas localidades, onde os portadores de cadernetas poderão facilmente transferir seus depósitos para a Caixa Econômica Federal ou para os bancos" (Moura, 1924, p. 45). A responsabilidade do estado nesse momento era estimada em mais de dezesseis mil contos de réis. A Caixa Econômica Estadual de Minas Gerais mostrou um volume de depósitos bastante menor do que a federal do seu estado, bem como em relação à paulista que era cerca de cinquenta vezes maior em 1940.

A caixa paulista foi criada pela lei estadual 1.544 de 30 de dezembro de 1916, regulamentada pelo decreto 2.765 de 19 de janeiro de $1917^{33} \mathrm{De}$ acordo com a lei, a caixa foi "destinada a receber pequenos depósitos e a estimular a formação de pecúlios populares”. O estado de São Paulo responsabilizou-se pelos depósitos, que rendiam juros não excedentes a $5 \%$ ao ano, capitalizados semestralmente. Por fim, elas foram autorizadas desde o início a realizarem empréstimos de preferência na sua respectiva localidade.

A caixa paulista apresentou um crescimento bastante acelerado nos seus primeiros anos de atuação, já rivalizando com a federal no estado no meado da década de 1920, como mostramos o gráfico 8 abaixo. Se no início da década de 1920 a estadual mantinha valores reais ainda inferiores

\footnotetext{
${ }^{31}$ Serviço de Estatística Econômica e Financeira do Tesouro Nacional (1940, p. 68 e 1945, p. 72).

${ }^{32}$ Além das caixas federais e estaduais, existiam diversas caixas privadas, das quais algumas populares e na forma de cooperativas.

${ }_{33}$ Recuperado de http://www.al.sp.gov.br/repositorio/legislacao/lei/1916/lei-1544-30.12.1916. html e http://www.al.sp.gov.br/repositorio/legislacao/decreto/1917/decreto-2765-19.01.1917.html.
} 
aos da federal, na segunda metade da década ela acumulou depósitos em montantes semelhantes, chegando a superar a do governo federal ao final da década. A maior interiorização das agências da caixa estadual facilitou a captação de depósitos relativamente a federal. A partir de sua regulamentação, ela criou suas primeiras agências em 1917, mas já ao final do ano seguinte detinha 56 agências (Contel, 2006). O Anuário do estado referente ao ano de 1939 apresentava depósitos em 198 municípios. ${ }^{34}$ Esta rápida expansão facilitou a captação de novos depósitos.

Na década de 1930, as duas caixas apresentaram tendência de crescimento dos depósitos, principalmente a estadual ao final da década. Apesar de pequenas diferenças dos movimentos de depósitos das duas caixas paulistas, elas apresentaram forte correlação dos seus valores depositados no período de comparação $(0.984) \cdot{ }^{35}$ Destarte, a soma dos depósitos das duas caixas paulistas representou quase a metade do total das caixas federais e a estadual de São Paulo em 1929, mas superavam a metade em 1940 (50.7 per cento).

Em 1938, a caixa paulista detinha quase 100000 cadernetas de depósitos, mantendo um valor médio bem superior ao da Federal, 7.4 contos de réis contra 1.7 respectivamente. Como ocorreu com as caixas federais que passaram a realizar empréstimos, a Caixa Estadual Paulista emprestou recursos ao Banco Hipotecário (depois ao Banespa) a partir de 1918 para o crédito agrícola (Costa, 2004). Segundo o balanço da caixa estadual da capital de São Paulo de 1939, quase a metade do ativo encontrava-se depositado em conta corrente no Banespa (49.5\%), superando o no Tesouro do estado (31.8\%) e em empréstimos e penhores (16.0\%, ver Folha da Manhã, ano XV, n. 4.891, 17 de fevereiro de 1940, p. 7). Dessa forma, verificamos a importância da Caixa Econômica Estadual de São Paulo para a captação de depósitos depois da primeira grande guerra. ${ }^{36}$

No gráfico 9, fornecemos a soma dos depósitos das duas caixas econômicas paulistas em relação à população do estado. Notamos, para o início

${ }^{34}$ Departamento Estadual de Estatística, 1940, pp. 835-840.

${ }^{35} \mathrm{O}$ relato do impacto da crise de 1929 sobre a Caixa Econômica Estadual de Campinas revelou-se similar a de outras localidades: "Nos últimos meses desse mesmo ano, ao rebentar a crise, houve uma corrida, provocada por notícias alarmantes sobre o estado precário do Tesouro do estado. No mês de novembro, as retiradas ascenderam a 1523 [contos] tendo alcançado só no dia quatro a soma de 431 [contos]. A caixa, porém, atendeu a todos os depositantes e, readquirindo-lhes novamente confiança, pode em pouco tempo retomar a sua vida normal" (Estado de São Paulo, LVII, n. 18935, 13 de setembro de 1931, p. 6).

${ }^{36}$ Não obstante a confiança da população na instituição, verificamos a ocorrência de algumas fraudes. A mudança do sistema de controle da caixa para mecânico foi visto como permitindo maior controle dos depósitos, apontando desfalques, como informa o artigo $O$ desfalque na Caixa Econômica Estadual (cf. Estado de São Paulo, LIX, n. 19444, 18 de março de 1933, p. 9). Mais tarde, houve estelionato para sacar depósitos de menores (ver Estado de São Paulo, LXV, n. 21426, 5 de agosto de 1939, p. 7). 


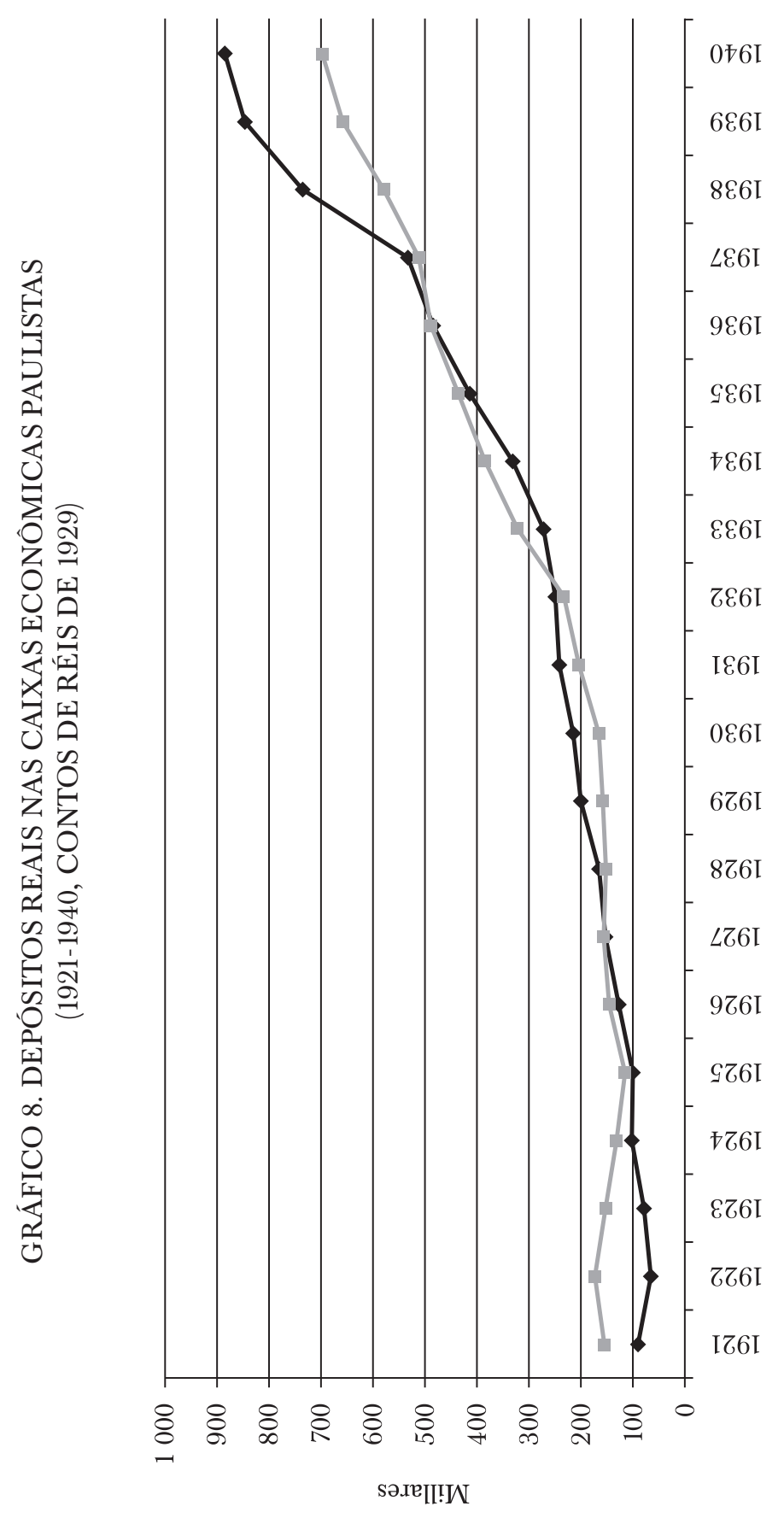

ำำ용

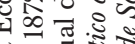

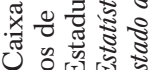
U

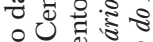

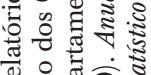

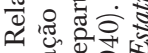
은 \% ㅇํㅇ 论跣

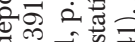

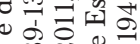
แ $\infty$ 원

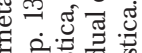

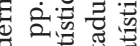

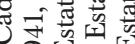

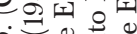
잉

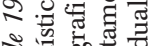
\&

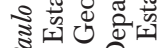
$\therefore$ ० 0 . 8 进 \& 50 . ․ $\overrightarrow{8}$ o षै० एᄂ, 0

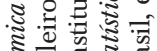

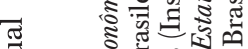
ร

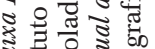
8 84.

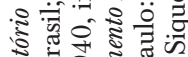

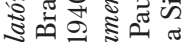
ช 0 0 远. 응

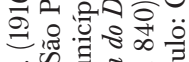
政表 ํㅕㄴ 1. 论

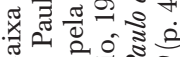
ชิ 我记

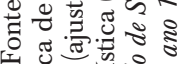

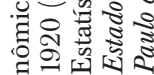


da década de 1920, uma pequena retração dos depósitos por 1000 habitantes, mantendo-se inferior a 50 contos. Entretanto, já a partir de 1926 houve um avanço contínuo da razão, mesmo durante a crise de 1929. Ao final do período, os depósitos chegaram a mais de 200 contos por 1000 habitantes do estado.

Estas evidências para as caixas paulistas salientam o alargamento das transações e a grande difusão delas para a capitação de depósitos. Nos anos 1930, essas instituições em conjunto com as demais caixas públicas dos outros estados, assumiram papel fundamental para o provimento de recursos para diversas finalidades, financiando imóveis urbanos, companhias anônimas e até o próprio governo.

\section{CONSIDERAÇÕES FINAIS}

Ao acompanharmos os depósitos populares captados pelas caixas econômicas públicas verificamos sua grande difusão em relação aos habitantes das duas capitais do país, embora a população rural e das menores cidades estivessem distantes das agências destas instituições. Desde o início das operações das caixas, o número de cadernetas e os depósitos reais cresceram a taxas superiores à da população, salientando a presença até de escravos, além de menores e principalmente mulheres. Quando analisamos relativamente às demais instituições bancárias, verificamos a elevada importância das caixas. Apesar da grande expansão do Banco do Brasil após a primeira grande guerra, as caixas mantiveram depósitos de pelo menos a metade do total do banco, crescendo nos anos 1930. Se compararmos com o movimento bancário e mesmo o PIB, verificamos uma menor participação nos anos 1920, refletindo a dificuldade relativa de captação das caixas nesse período. Contudo, elas apresentaram um forte crescimento relativo aos bancos e PIB nos anos 1930, salientando a demanda por depósitos em instituições públicas durante a grande crise dessa época. Por fim, a Caixa Estadual Paulista cresceu rapidamente após a primeira grande guerra, captando depósitos de forma ampla pelo estado, mesmo nos anos 1920. Nos anos 1930, as caixas diversificaram a sua atuação, realizando empréstimos de diferentes tipos, especialmente imobiliários urbanos. Mesmo após a reorganização elas continuaram como um importante instrumento de captação de depósitos populares, como na origem da instituição em 1861. 

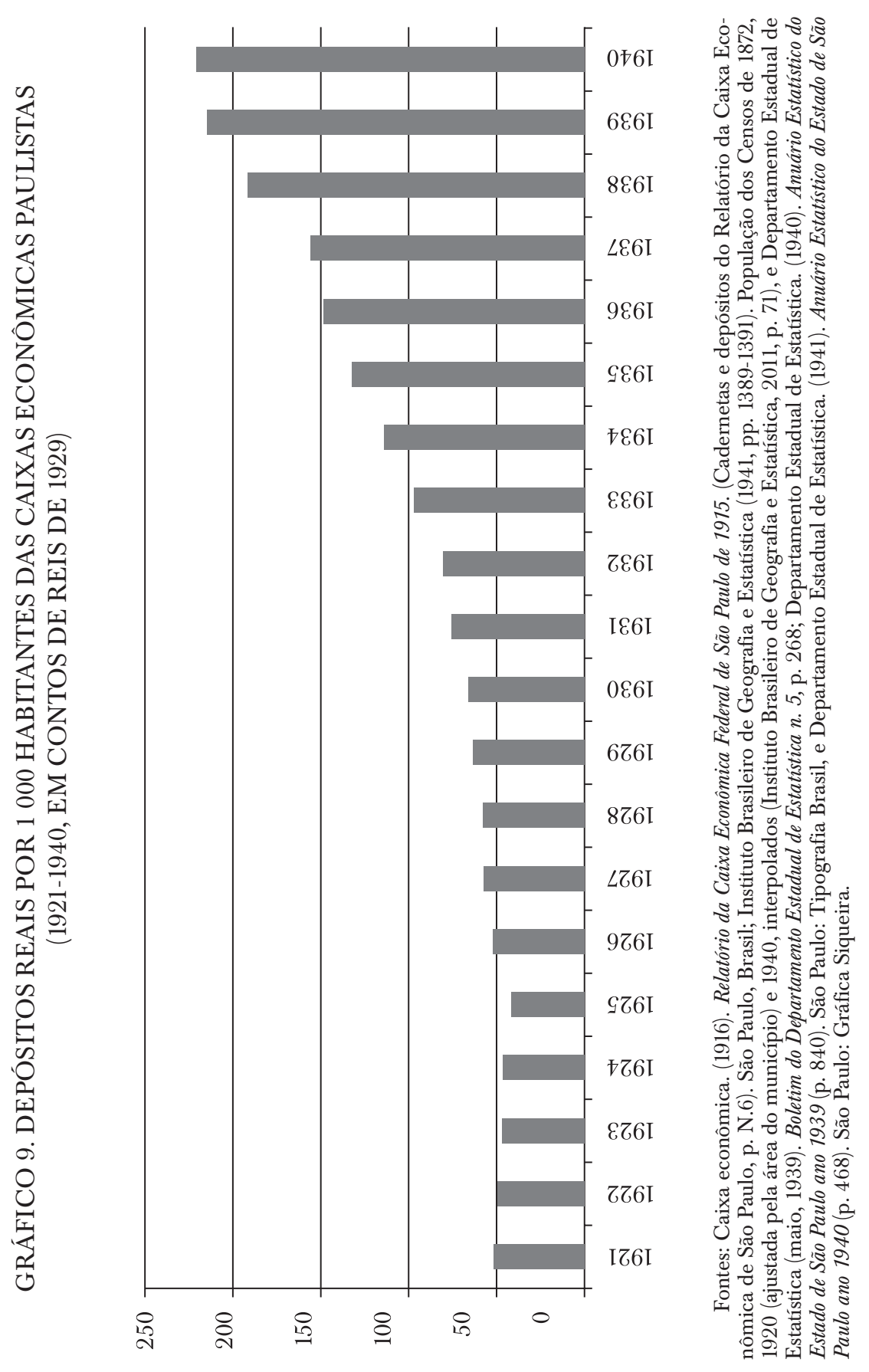


\section{REFERENCIAS}

Adams, A. A. (2005). The Caixa econômica: A social and economic history of popular banking in Rio de Janeiro, 1821-1929 (Tese doctoral). Harvard University, Massachusetts.

Banco do Brasil (2010). História do Banco do Brasil. Belo Horizonte: Del Rey-Fazenda Comunicação \& Marketing.

BRASil. MinistéRIO dA FAZENDA (anos 1884, 1890, 1895, 1906, 1909, 1914, 1916). $R e$ latórios do Ministério da Fazenda. Rio de Janeiro: Typographia/Imprensa Nacional. Recuperado de http://www.crl.edu/brazil/ministerial/fazenda

Bueno, E. (2002). Caixa: uma historia brasileira. Porto Alegre: Buenas Ideias Metalivros. CAIXA ECONÔMICA (1902). Relatório da Caixa Econômica e Monte Socorro da capital Federal do ano de 1901. Rio de Janeiro: Imprensa Nacional.

CATÃo, A. V. (outubro-dezembro, 1992). A new wholesale price index for Brazil during the period 1870-1913. Revista Brasileira de Economia, 46(4), 519-533.

Contel, F. B. (2006). Território e finanças: técnicas, normas e topologias bancárias no Brasil (Tese doctoral). Universidade de São Paulo, São Paulo.

Costa, F. N. (2012). Brasil dos bancos. São Paulo: Universidade do São Paulo.

Costa, Y. C. (2004). Bancos oficiais no Brasil: origens e aspectos do seu desenvolvimento. Brasília: Banco Central do Brasil.

Diretoria de Estatística Econômica e Financeira do Tesouro Nacional (1938). Quadros estatísticos: resumo anual de estatísticas econômicas 1930-1937, núm. 2. Rio de Janeiro: Typographia da Directoria de Estatística Econômica e Financeira. Recuperado de www.memoria.nemesis.org.br

Estado de SÃo PAulo (13 de setembro, 1931). Campinas. Economia campineira: a situação das populações pobres do município vista através do movimento da Caixa Econômica Estadual. Estado de São Paulo. 50(18935), 6.

Frank, Z. L. (2004). Dutra's world: Wealth and family in nineteenth-century Rio de Janeiro. Albuquerque: University of New Mexico Press.

Goldsmith, R. W. (1986). Brasil 1850-1984: desenvolvimento financeiro sob um século de inflação. São Paulo: Haper \& Row.

GrinberG, K. (2011). A poupança: alternativas para a compra da alforria no Brasil (2a. metade do século XIX). Revista de Indias, 71(251), 137-158.

HadDaD, C. L. S. (1978). Crescimento do produto real no Brasil, 1900-1947. Rio de Janeiro: Fundação Getúlio Vargas.

Instituto Brasileiro de Geografia e Estatística [ibGe] (1941). Anuário Estatístico do Brasil 1939-1940. Rio de Janeiro: Instituto Brasileiro de Geografia e Estatística.

Instituto Brasileiro de Geografia e Estatística [ibge] (2011). Sinopse do Censo Demográfico 2010. Rio de Janeiro: Instituto Brasileiro de Geografia e Estatística.

Marques, T. C. N. e Melo, H. P. (maio-agosto, 2008). Os direitos civis das mulheres casadas no Brasil entre 1916 e 1962. Ou como são feitas as leis. Estudos Feministas, 16(2), 463-488. 
Mello, Z. M. C. (1985). Metamorfoses da riqueza: São Paulo, 1845-1895. São Paulo: Hucitec/Prefeitura do Município de São Paulo.

Moura, R. S. (1924). Mensagem ao Congresso Mineiro de 14 de julho de 1924. Belo Horizonte: Estado de Minas Gerais.

MÜLleR, E. (s. f.). Moedas e bancos no Rio de Janeiro no século XIX: versão preliminar. Rio de Janeiro: Universidad Federal de Rio de Janeiro. Recuperado de http://www. ie.ufrj.br/eventos/seminarios/pesquisa/moedas_e_bancos_no_rio_de_janeiro_ no_seculo_xix.pdf

Peláez, C. M. e Suzigan, W. (1981). História monetária do Brasil: análise da política, comportamento e instituições monetárias. Brasília: Universidade de Brasília.

SÁEz, H. E. L. (2010). O 11 de setembro de 1864 da praça carioca: a crise do Souto e a transformação da política econômica brasileira. Anais do XXX Encontro da APHES. Lisboa: Universidade Técnica de Lisboa. Recuperado de http://www.iseg.utl.pt/ aphes30/docs/progdocs/HERNAN\%20SAEZ.pdf

SARAIVA, L. F. (2002). Estrutura de terras e transição do trabalho em um grande centro cafeeiro, Juiz de Fora 1870-1900. X Seminário sobre a Economia Mineira. Belo Horizonte: Universidade Federal de Minas Gerais.

SeCKler, J. (1888). Almanach da província de São Paulo: administrativo, commercial e industrial para 1888. São Paulo: Jorge Seckler \& Co.

Serviço de Estatística Econômica E Financeira do Tesouro Nacional (1940). Quadros Estatísticos: resumo anual de estatísticas econômicas 1930-1937 N. 3. Rio de Janeiro: Imprensa Nacional. Recuperado de www.memoria.nemesis.org.br

Serviço de Estatística Econômica E Financeira do Tesouro Nacional (1945). Quadros Estatísticos: Brasil 1933-1942. Rio de Janeiro: Imprensa Nacional. Recuperado de www.memoria.nemesis.org.br 